\title{
SKULLS FROM TIWANAKU: A FORGOTTEN PART OF NESTLER'S COLLECTION IN THE HRDLIČKA MUSEUM OF MAN IN PRAGUE
}

\author{
Markéta Kř́ržová ${ }^{1}$
}

\begin{abstract}
Julius Nestler, high school teacher and amateur archaeologist from Prague, brought home more than 3,500 archaeological and anthropological artifacts from his expedition to Bolivia (1909-1912). At present they are in the possession of the Náprstek Museum in Prague. a smaller corpus of human bones, especially skulls, some deformed (elongated) and/or trepanned, were deposited at the Hrdlička Museum of Man (Charles University in Prague). Nestler's second collection has not, so far, received much attention from anthropologists, museologists or historians of science, one of the reasons probably being the fact that there is no preserved documentation as to its provenance. Sources dispersed in several archives and publications made it possible to ascertain Nestler's motivation for collecting human remains, the location where he collected them, and the circumstances of their sale to Charles University. The article also aspires to insert the collection and its original owner into the broader context of anatomical and anthropological disciplinary practices in the Czech Lands in the first decades of the $20^{\text {th }}$ century.
\end{abstract}

KEYWORDS: history of physical anthropology - history of museum collections - human skulls - artificial deformation - Julius Nestler - Tiwanaku - Náprstek Museum - Hrdlička Museum of Man

The present article revolves around a case study, the mapping of the history of a collection of human remains preserved in the Hrdlička Museum of Man which constitutes part of the Faculty of Natural Sciences of Charles University. Julius Nestler, high school teacher and amateur archaeologist from Prague, spent the years 1909-1912 in Bolivia, mostly in and around the famous archaeological site of Tiwanaku. ${ }^{2} \mathrm{He}$ brought back more than 3,500 archaeological and anthropological artifacts, at present in the possession of the Náprstek Museum. Nestler's biography, the circumstances of his voyage to South America and of his acquiring the collection have already been documented. ${ }^{3}$ But Nestler also assembled in Bolivia a smaller corpus of human bones, especially skulls, some deformed (elongated) and/or trepanned. It needs to be admitted that, generally speaking, this collection is not remarkable when compared

1 Contact: Markéta Kř́žová, Faculty of Arts, Charles University/ Academy of Sciences of the Czech Republic, Prague, Czech Republic; e-mail: marketa.krizova@ff.cuni.cz. The study is the result of the research project supported by the Grant Agency of the Czech Republic 'Evolutionalism, nationalism and racism in Czech and Slovak science (1882-1948): dialogue between the social sciences and biology' (GA 19-03474S).

2 The contemporary spellings of the name of the site varied. I will maintain these when quoting directly from the primary sources; however, throughout the present text I will use the modern spelling 'Tiwanaku'.

3 Kř́žová 2016. 
with the holdings of many European and North American museums. But deformed and trepanned skulls, and generally skulls from non-European regions, were and still are rare in the Czech context, a fact commented upon already in the 1920s when the Charles University acquired the collection.

This article is, first and foremost, an effort to construct, from the scanty documentation, a 'biography' of this collection, so that it can be of more use to present-day scholars. Neither of Nestler's two collections has, so far, received much attention from anthropologists, museologists or historians of science, due to the fact that there is no preserved documentation as to the provenance of the specimens. Secondary sources dispersed in several archives and publications made it possible to ascertain Nestler's motivation for collecting human remains in America, as well as the circumstances of their sale to Charles University. The conceptual framework for this type of study is the 'biographical' approach to museum collections and museum artifacts, inspired by the 'cultural biography' approach to material culture of Arjun Appadurai and Igor Kopytoff that aims to elucidate how certain objects or collections of objects acquired new meanings and increased in symbolic and material value as they were collected, studied, displayed, and exchanged. ${ }^{4}$

Secondly, the article aspires to insert the collection and its original owner into the broader context of anatomical and anthropological disciplinary practices in the Czech Lands in the first decades of the $20^{\text {th }}$ century, as these were shaped by political, racial, and nationalist/ethnic considerations, and thus to ascertain the specificities of the development of Czech anthropology and anthropological museology in the late $19^{\text {th }}$ and early $20^{\text {th }}$ centuries. As most of the documentation for this phase of intellectual development is in Czech, its study has so far been restricted to Czech scholars. Last but not least, the text also aspires to be a brief invitation for further discussion of the continued presence of human remains in Czech museums, within the frame of the even more complex problem of the postcolonial heritage of a country that did not possess colonies, but was not lacking colonial ambitions and dreams.

\section{Skull collecting in broader context}

To put the specific case of the Nestler collection and the more general problem of early anthropological museology in the Czech lands into context, it is necessary to start with a brief summary of some well-known facts. Anthropology, the science of the study of man, was established as a standard academic discipline and its objectives and methods were defined in the course of the $19^{\text {th }}$ century within the frame of the second colonialist thrust of European countries to other continents. The apparently highly intellectual, specialized systems of knowledge thus immediately acquired political relevance, as through anthropology the supposed superiority of the white European was established as a rationalized, positive 'truth'. Central to these arguments was the concept of race that originated, in its modern meaning, in $18^{\text {th }}$ century zoology and later was applied to humans by Johann Friedrich Blumenbach. ${ }^{5}$ During the $19^{\text {th }}$ century, scientists refined the concept of race, taking it far beyond the initial taxonomic purpose, and at the same

4 Appadurai 1986; Kopytoff 1986. For the examples of 'biographies' of museum objects see Fenn 1997; Roque 2011; Basu 2011; Foster 2012; Feldman 2016 etc.

5 Edwards 1994, p. 6. 
time diversified the system that Blumenbach originally based solely on skin color, including measurements of body parts and their comparisons to the construction of racial taxonomies and evolutionary sequences. These methods gained prominence over the older interpretations of evolution and diversity of mankind, based on philology and the study of culture and religion. ${ }^{6}$

Within these studies, the skull was given priority, as it offered itself for multiple measurements and calculations of ratios. Of course, throughout human history various cultures and civilizations had ascribed vital value to this most recognizable part of the skeleton. ${ }^{7}$ Besides its pervasive symbolism, reflected also in European visual arts and literature from Antiquity onwards, the fact that the skull was 'naked' was important from the point of view of $19^{\text {th }}$ century anthropologists. It seemed to be resistant to the impacts of climate and the natural environment as well as to lifestyle and culture. In contrast to the tissues covering it during the person's lifetime, the shape of the skull seemed to remain stable over generations, thus also allowing for the study of the laws of descendance. And, finally, there was the presumed connection between the skull and intelligence. The measurements of skulls and their components, especially of the brain (craniometry), became the privileged occupation of professional as well as amateur anthropologists. ${ }^{8}$

Comparison was crucial in craniometry, and there was an acute need for extensive collections, private as well as institutional, containing hundreds and thousands of skulls and other osteological remains. As with other types of scientific displays, such as natural specimens or archaeological and ethnographical artifacts, and due to the dynamic development of museums and other scientific institutions, a lively exchange and marketing of these exhibits was going on. Human remains were thus not only given the status of scientific objects, but also saleable commodities. 'Bone hunting' on occasions included violation of cemeteries, digging up very recently buried bodies, and competition for the skeletons of still-living persons. ${ }^{9}$ Moreover, in the situation of ongoing colonial expansion, the possession of the bodily remains of the colonized people and their reduction to objects of study and sale served as one of the manifestations of political and cultural superiority of Europe over the rest of the world. In the words of one of the historians of this trade, skull collecting became a variant of 'trophy-taking'. ${ }^{10}$

As for the Andean region of South America, it had since colonial times been famous as a place of discovery of well-preserved human remains from various time periods. Because of the extremely arid climate in the coastal regions and highlands that made their preservation possible, many collections contained specimens from this region. There are frequent mentions in travelogues from the colonial period of European visitors literally stepping on skulls and bones that were littering their path. ${ }^{11}$ At the turn of the $20^{\text {th }}$ century Andean collections were abundant in museums in Europe as well as in North America, and were highly praised as study material. It was believed that the history of migration in the American continent could be elucidated through the lens

6 Giesen and White 2013, p. 15; also Achim 2014; Gould 1996.

7 Quigley 2001, p. 5.

8 Zimmerman 2001, 86; for the contemporary method of skull measuring, Broca 1875.

9 Legassick and Rassool 2000; Redman 2016.

10 Challis 2013, p. 176; also Roque 2010.

11 Wafer (1688) 1934, p. 122. 
of the morphological variability of these remains. In the opinion of Aleš Hrdlička, the curator of the anthropological collection at the Smithsonian Institution:

Peru may well be regarded, even in its present territorial restriction, as the main key to the anthropology of South America. Due to the numbers of its ancient inhabitants, and to their far reaching social differentiations indicating long occupancy, a good knowledge of the people of Peru from the earliest times is very desirable, and would constitute a solid basis from which it should be relatively easy to extend anthropological comparison to all the rest of the native peoples of the Southern Continent. ${ }^{12}$

In 1910 and 1913, Hrdlička himself travelled to the Andes to gather materials that could shed light on the peopling of the Americas, and the development of racial types. ${ }^{13}$ The German anthropologist Rudolf Virchow too believed that the osteological material from the Andes could help them to respond to respond to 'questions concerning the origin of Americans' ${ }^{14}$

Besides, what attracted the attention of the scholars was the quantity of deformed skulls in the Andes. The custom of artificial head deformation had appeared in various parts of the world and at various time periods since Antiquity, 'having originated independently in many quarters, from some natural impulse common to the human race' ${ }^{15}$ But in the Andes it seemed almost omnipresent. Some of the professional anthropologists considered them valueless precisely because the deformation complicated the comparisons and approximations and the establishing of a 'standard' for various races. The curator of the anthropological collection at the Smithsonian Institution, Aleš Hrdlička, complained that while there were many hundreds of Peruvian skulls scattered in North American museums, the majority of these skulls were deformed. For Hrdlička this rendered them unsuitable for 'anthropological determinations ${ }^{16}$ But deformations at the same time provoked other types of queries, especially with respect to brain size and shape and the possible relation of these to the intellectual and cognitive capacity, or the possible heredity of such deformations (which Virchow, for example, strictly denied). ${ }^{17}$

Reports from colonial Andes gave evidence of the practices for molding infant heads to achieve specified shapes, especially by binding; in some regions at least, this practice continued up to the $18^{\text {th }}$ century. ${ }^{18}$ In contrast, the trepanations - drilling or scraping holes through the skull to treat intracranial diseases or injuries - were not mentioned in colonial documentation, but were also frequently represented in Andean skull collections. It was precisely a specimen from Peru that in 1867 was brought to the attention of international scientific community by the United States diplomat and amateur archaeologist Ephraim George Squier, via the French surgeon-anthropologist

12 Hrdlička 1911, p. 1; for Hrdlička see Loring and Prokopec 1994.

13 Feldman 2016.

14 Virchow 1892, p. 1.

15 Flower 1881, p. 34.

16 Hrdlička 1911, p. 2.

17 Virchow 1892, p. 19.

18 Skinner 1805, p. 269; for analysis of archaeological finds of cranial deformation Janusek 2004, pp. 161-162. 
Paul Broca, marking the start of an intense fascination with trepanation in the United States and in Europe. ${ }^{19}$ Besides being conspicuous and interesting to look at, trepanned and deformed skulls were apparently 'authentic', that is, ancient, and therefore prized by private collectors as well as institutions.

\section{Trip to Bolivia and its aftermath}

It was in this broad context that the journey of Julius Nestler to Bolivia took place. There is no need to repeat here more than the basic outline of his life and activities. Born in Prague in 1877, in a family of markedly German national allegiances, he pursued the career of a high-school teacher. In 1909 he traveled to Bolivia in search of the ancient 'cradle of civilization'. An even stronger instigation, however, was the increasing interest of scientific institutions in Central Europe in exotic displays. The selling of collections brought both financial gain and recognition as members of international scientific community for enthusiastic amateurs. It is clear from the preserved correspondence that even before departing Nestler planned to convert his would-be collections into money, even though he also cultivated a strongly nationalist rhetoric, presenting his research as a contribution to the promotion of German culture in the Czech Lands. ${ }^{20}$

In letters sent to the museums of Leipzig, Hamburg, and even the Smithsonian in Washington, in which Nestler applied for financial support for the journey and promised to deliver collections as repayment, ${ }^{21}$ he never offered to obtain human remains, even though all these institutions included them in their displays. Invariably he wrote only about archaeological excavations and collecting ethnographic and linguistic material. Nor did Nestler ever mention craniometry or other forms of the study of human body in texts from before the journey, or in his only comprehensive article published after returning from his Tiwanaku 'expedition'. ${ }^{22}$ When speculating about the 'Aryan race' - the alleged creator of the Bolivian ruins - he always resorted to cultural and linguistic arguments. It thus seems that Nestler realized the possibilities of the trade in human bones within the frame of the contemporaneous European 'culture of collecting' only on arrival in Bolivia,.

As for human remains, they were abundant in and around Lake Titicaca. In the words of the North American archaeologist Adolph Bendelier, who travelled in the area at the same time as Nestler:

the village of Tiahuanaco rests, as we have seen ourselves, on a thin layer of ashes, human and animal bones; also skulls! This layer is at a depth of from two to

19 On this skull, Fernando and Finger 2003, pp. 1-7; Squier 1877, pp. 455-457; on trepanation Broca 1878; Tello 1913 etc.

20 For further details see Kř́žžová 2016.

21 Nestler's letter to the museum of Leipzig of 20-IV-1908 in the Archive of the Grassi Museum, Leipzig (hereafter AGM), BW, no. 10352, in German. If not stated otherwise, all the translations from the sources are mine. a copy of Nestler's letter to Hamburg of 10-IV-1908, in German is deposited in the documentation to the Nestler Collection. in the Archiv Náprstkova Muzea, Prague [Archive of the Náprstek Museum, hereafter NpM], fund Spisy dárců NpM, sl. Nestler, f. 26); letter to Smithsonian of 17-XI-1907, in English, in National Anthropological Archives, Smithsonian Institution, Washington (hereafter NAA), MS. 4024 C - Personal letters received by John Wesley Powell.

Nestler 1913. 
three feet beneath the surface, its thickness varying from a few inches to a foot and more, and the crania are deposited in it promiscuously. ${ }^{23}$

Besides digging them from the ground, travelers could also get numerous skulls and other bones from the funerary towers (chullpas) scattered in great numbers all over the Peruvian and Bolivian altiplano. ${ }^{24}$ a law passed in 1906 that named the Bolivian nation as the rightful owner of the ruins of Tiwanaku prohibited the export of objects from this as well as other sites. ${ }^{25}$ This law did not explicitly mention human remains. Still, the above-quoted Adolph Bendelier complained about the complications caused by the new legislative:

The prohibition, by the Bolivian Government, to excavate in or about the ruins, rendered all subsoil investigation impossible and our limited collections were obtained almost by way of contraband; through purchase from Indians, who mostly came at night to avoid the vigilance of the authorities. ${ }^{26}$

In this way, Bandelier was able to obtain skulls as well, including those showing artificial deformities.

The interest of anthropologists of North America and Europe in human remains from the Andes and their disagreement with the politics of local governments who were trying to prevent their export - and also the lack of success of these efforts - is proven also by the exchange of letters between Aleš Hrdlička and Julio Tello, prominent representative of Peruvian archaeology. In 1916 Hrdlička wrote:

Recently we heard something which I hope is incorrect, and that is that the exportation of osteological material has been prohibited by Peru. This would be a decided step backward, and it would be against the interests of anthropology. Fortunately, we have now so much in this direction that at least a large part of the coast is covered. But whatever the new laws are concerning the exportation of antiquities, they must be administered very loosely, for recently there has been sent here from Peru a big and important collection of 'huacos', ${ }^{27}$ which is now being offered for sale; only, however, after about one-fourth of the total had been broken to bits and ruined. ${ }^{28}$

23 Bandelier 1911, pp. 233-234.

Yates 2011, p. 293.

Bandelier 1911, p. 218.

The term huaca in the Anden region denoted a religious structure or even a natural location (rock, mountain) associated with ritual, but also ceremonial objects. According to the Spanish conquistador and chronicler Pedro de Cieza de León the word guaca meant 'burial place'. (Cieza de León 2005, 63)

Hrdlička to Tello, Washington, 27-IX-1916, in English, Archivo Julio C. Tello, Museo de la Arqueología y Antropología de la Universidad Nacional Mayor de San Marcos (hereafter AJT), JCT/XXXI/B98a/Tomo III (Doctor Tello, Correspondencia, T. III, 1916-1920), f. 520. 
Further correspondence by Tello reveals the fact that he often made 'presents' of interesting skulls to his scientific partners abroad. ${ }^{29}$

As for Nestler, he probably proceeded in the same way as Bandelier; that is, he bought the human remains from local inhabitants. There is a statement in an article by Czech anthropologist Jan Malý who studied the skulls brought by Nestler after their acquisition for Charles University. (It seems that the information was passed orally, i.e. by Nestler himself, before or during the purchase.) Malý resumed the circumstances in the following way:

Dr. Nestler got the skulls from the natives who dug them out themselves and brought them to him wrapped in home-spun scarfs. According to the scientist the natives readily seek for this material, as they are Christians and so eagerly turn into money such 'pagan remnants'. ${ }^{30}$

This would mean, of course, that the skulls could come from anywhere in the vicinity of La Paz. According to Malý, the chemical analysis of the residues of soil on some of the skulls had proven their provenance from the same place, ${ }^{31}$ but, of course, without soil samples with which to make comparisons, he was not able to specify the locality.

After returning to Europe in 1913, Nestler tried to sell his ethnographic and archaeological collection to German museums; but in the end in 1921 these were purchased by the government of the new Czechoslovak Republic. ${ }^{32}$ In contrast, the osteological specimens he probably offered straight to the Anthropological Institute of Charles University, founded within the recently established (in 1920) Faculty of Natural Sciences of Charles University. The circumstances of the sale of Nestler's collection of skulls are mentioned in a letter from December 19, 1920, addressed by the director of the institute and the first professor of anthropology (from 1908) at that University, Jindřich Matiegka, to Aleš Hrdlička, who served as an important patron of Czech anthropology. Nestler and Matiegka both took part in the Sixteenth International Congress of Americanists in Vienna in 1908. ${ }^{33}$ Also, the exhibition of Nestler's archaeological collections in the Museum of Decorative Arts in Prague in 1919 that preceded its sale to the Czechoslovak state was inaugurated by a lecture delivered by Vojtěch Schück/Suk, Matiegka's assistant in the Anthropological Institute. This hints at an already existing connection between Nestler and the Institute.

29 For example, Leonard Freeman from Denver thanked Tello in 1922 for 'the wonderful skull which you were kind enough to present to me. I value it more than anything else I obtained in Peru, or anything that I could have obtained. I have long wanted such a skull and it was a great satisfaction to be able to get such a good specimen. (Leonard Freeman to Tello, 17-III-1922, in English, AJT, JCT/XXXI/B98a/ Tomo IV (Doctor Tello, Correspondencia, T. IV, 1921-1925), f. 774); for Tello see Burger 2009.

30 Malý 1926, p. 252.

31 Ibid., p. 252.

32 Kř́ižová 2016.

33 In a letter sent to Matiegka, dated 16-II-1915, in which he asked for contacts to the publishers of Czech archaeological journals, Nestler alluded to this joint participation in the international congress. This letter, however, does not mention the collection of anthropological material. (The letter preserved in the Archive of National Museum [Archiv Národního muzea], fund 246 [Jindřich Matiegka], box 8, in German.) 
In the above-mentioned letter from December 1920, Matiegka enthusiastically described to Hrdlička a recent 'precious acquisition', collection consisting of: 12 nicely preserved, 6 damaged skulls, mostly still covered with soil, or tied in bundles. Also a number of long bones, frontal and occipital bones. Of the skulls 2 are not deformed, the others deformed, some to highest degree; one has unhealed, 2 healed trepanations.

Matiegka also mentioned the price, 1,200 Czechoslovak crowns, considering the price 'rather cheap', as one Peruvian skull could cost up to 400 German marks. Besides, it is clear from this letter that it was Matiegka who actually persuaded the Czechoslovak authorities to buy the archaeological part of the collection as well, 'as we do not have anything similar' in the field of pre-Colombian antiquities in the museum collections of the newly established state. ${ }^{34}$

This mention in the letter by Matiegka is one of many proofs of the extreme competitiveness that marked the development of science in the Czech lands in the late $19^{\text {th }}$ and early $20^{\text {th }}$ century. In their effort to prove that they could qualify as a fully-fledged and civilized nation, and especially that they were able compete with the Germans in all fields of intellectual and cultural activity, the Czechs pursued research, established scientific terminology, published or translated specialized treatises and amassed museum collections. The argument that some scientific activity should be realized because of what happened in the museums and at universities abroad or that the researcher was able to display 'collections richer than those in Berlin' ${ }^{\prime 35}$ appeared relatively frequently.

\section{Exotic skulls at Charles University}

The archaeological and ethnographical collections of Nestler were deposited in the Náprstek Museum immediately after their purchase by the Czechoslovak state. We have to ask why the osteological collection was bought and deposited separately. Museums in Europe and North America commonly included them among archaeological and ethnographical exhibits because of the crucial role of human remains in the study of human history. The Ethnological Museum (Museum für Völkerkunde) in Leipzig, opened in the 1870s, can serve as an example. The visitor was first led to explore 'the bodily nature of mankind', that is, skeletons, skulls, mummies, and 'palaeontological finds', as well as various body parts in jars; only in the next rooms were the cultural artifacts displayed. ${ }^{36}$ Similar logic was applied to exhibitions in British, French, and North American museums.

But the circle around the Náprstek Museum ever since its establishment manifested little interest in human remains. There was the tsantsa, a shrunken human head for which the Jivaros of Ecuador were famous, donated to the museum in the end of the $19^{\text {th }}$ century by the traveler Enrique Stanko Vráz. But, characteristically, the

34 The letter is preserved in NAA, fund Hrdlička Papers, box 44, Matiegka II (1914-22), in Czech.

This was how the Czech traveler and amateur anthropologist Vojtěch (Alberto) Frič justified his voyages of exploration and his efforts to build in Prague a museum dedicated to South American Indians (see document annex in Frič 1977, pp. 242-243; for the specific motivations of Frič in his anthropological research, especially his clashes with the nationalistic ambitions of German anthropologists, see Penny 2003). 
museum register specified that it was the 'head of a chief', thus presenting the artifact in a cultural - or even sensationalist - rather than biological way. ${ }^{37}$ In the 1920s, the museum also acquired three overmolded skulls (i.e. skulls covered with material to re-create facial appearance) from Australia, as part of the collection donated by the naturalist and traveler Jiří Viktor Daneš, but again they were treated as ethnographic artefacts (heads of ancestors), not as biological specimens. ${ }^{38}$ Perhaps this exclusively cultural orientation stemmed from the original concept of the industrial museum, in spite of its being soon distorted by the integration of numerous exotic 'souvenirs' in the exhibition. Of the Czech travelers, apparently only Vojtěch (Alberto) Frič collected and sold human remains, but he never exhibited them in the Czech Lands or offered them to the Náprstek Museum. Instead, Frič sold his osteological collections to other institutions, such as the Ethnological Museum of Hamburg and the Smithsonian Institution. ${ }^{39}$

The Náprstek Museum thus left all the initiative in the study of non-European human specimens to the biological scientists, mostly professors of Prague University. Anthropological research was practiced in the Czech Lands, although sparsely, including craniometry of both contemporaneous and ancient men, as early as in the second half of the $19^{\text {th }}$ century. It took root at the university as a standard field of study at the very end of the century, first in connection with archaeology, then emancipating itself as a specialized discipline. This was due especially to the efforts of Jindřich Matiegka (who was in 1904 named the first 'professor of demography and anthropology') and the financial and intellectual support of Aleš Hrdlička, who migrated to the USA with his family in the 1880s as an adolescent, but throughout his whole life maintained contacts with his native country, endowed its scientific institutions and promoted their results in North American periodicals.

Czech physical anthropologists were mostly responding to German anthropology under Virchow. Their ultimate goal was to bolster Czech national identity, and prove the biological existence of a specific 'Czech type'. They used anthropometry and craniometry to demonstrate the essential equality with (or even superiority over) the German population in the Czech Lands. Together with ethnological research that brought proofs of cultural equality, such research was to give material proof to further the aspirations of Czechs to independent statehood, and to foretell their future. ${ }^{40}$ The race debates also resonated in Czech intellectual circles, as did the debates on Darwinism, but were also adjusted to serve local needs, especially the political, intellectual, and economic competition with the Germans. ${ }^{41}$ Considered as a way to capture the nation's past, the study of ancient graves and the remains of 'ancestors' thus became highly relevant from the political point of view. With all these diverse aims in view, shortly after the founding of Czechoslovakia Aleš Hrdlička provided

37 Škrabáková 2019.

38 Jungová 2017.

39 In a letter to Aleš Hrdlička, in which he offered human skulls for sale, Frič also mentioned that he sold others to Hamburg. (Letter dated 15-I-1908, in Czech, preserved in NAA, fund Hrdlička Papers, Correspondence, Box 24, folder FRE-FZ.)

40 Grégr 1858, cit. in Herza 2016, p. 72. Tomsová 2014, p. 58 quoted the words of Aleš Hrdlička: ‘We need to study anthropologically the Slavs so that we can identify their physical characteristics, establish their origin and predict their development in the future.'

41 Janko 1997. 
considerable funding. This that made possible the establishment of the Anthropological Institute and later its museum, the publication of the journal Anthropologie, and the realization of various research projects - among them archeological excavations in Moravia - and study trips abroad for younger Czech scholars. ${ }^{42}$

At the same time, there was a long-term interest in exotic anthropometry among Czech anthropologists, again closely imitating the pursuits of German anthropologists. The non-European skeletons and skulls were to serve as a comparative material for ascertaining the specificities of Czech racial type, especially with respect to prehistorical remains, and to enrich the museum collections. It was not easy, of course, to obtain such exemplars in Central Europe. For example, Vasil Kanjuk, a 'Samoyed', died in Prague on August 20, 1882. He was a member of one of the performance shows that responded to the increased hunger for exotic especially among the bourgeois classes in Europe and North America, and at the same time to the establishment of physical and cultural anthropology as scientific disciplines with a need for study material. ${ }^{43}$ The body of Vasil was examined and dissected at the Anatomical Institute of the Charles University in Prague, then buried at the city cemetery, but ten years later Jindřich Matiegka disinterred it and again measured and analyzed the bones and the skull. The skull was then deposited in Matiegka's osteological collection and later transferred to the Hrdlička Museum of Man, where it rests to this day. In an article published in the journal of the anthropological association of Vienna, Matiegka made use of Vasil Kanjuk's skull for discussing comparative differences between races. ${ }^{44}$

This case not only shows the importance of exotic specimens for the nascent anthropological science in the Czech Lands, but also the matter-of-fact, probably even unconscious sense of superiority of Czech intellectuals over the men and women they studied, and their conviction that their pursuit of scientific progress legitimized even practices that were at odds with the moral or even legal regulations of the times. ${ }^{45}$ The Czech scholars - and, of course, their counterparts in other regions of Europe frequently acquired specimens from medieval cemeteries or other locations. ${ }^{46}$ Bodies, skulls, and brains of prominent individuals were sometimes sectioned and examined after their death, as was the case of the most renowned Czech intellectual, historian,

42 Škerlj and Božek 1952; Škvařilová 2010.

43 For the ethnographic shows, see Bancel et al. 2012.

44 Matiegka 1893; the case resumed by Herza 2018, 177.

45 I am leaving aside the very specific case of the anthropological study of the Egyptian mummies, popular intellectual occupation over Europe since the early $19^{\text {th }}$ century. This topic was, for the specific case of the Czech Lands, been already dealt with, for example by Onderka et al. 2015.

46 The correspondence between Matiegka and Hrdlička, preserved in the Archive of the Charles University and in the Archive of the Smithsonian Institution, give numerous examples of their fascination with skulls and the mutual exchanges of specimen. Thus in a letter from April 13, 1908, Hrdlička announces the dispatch of several North American skulls that he obtained at native burial place during his journey to the West; in a letter of November 13, 1909, Matiegka replied by announcing the finding of several 'well preserved skulls' from an abandoned cemetery in Prague, also promising to send some to Hrdlička. (Both letters in the Archive of Smithsonian Institution, fund Papers of Aleš Hrdlička (herafter ASI-PAH), box 44, file 'Matiegka'). 
and politician František Palacký. ${ }^{47}$ In other words, the objectification of human remains certainly was not reserved for non-European 'savages'.

Within the frame of their endeavor to prove the capacity of Czech language to grasp scientific topic, the Czech anthropologists, like the representatives of other disciplines, often reproduced information given in texts by foreign colleagues. Thus Matiegka also wrote one short text on prehistoric skull deformations, in which he mostly summarized existing knowledge, especially that contributed by Hrdlička, and hinted at the possibilities of comparative study of such deformations; but without actually producing anything new or referring to any research done in the Czech Lands. ${ }^{48}$ The need for the study of 'primitive races' in the Czech milieu was also advocated by Aleš Hrdlička in his proposal to establish an anthropological research institute in Prague, an equivalent of the École d'anthropologie in Paris. 'The absence of overseas settlement and the possession of primitive tribes would not cause any inconvenience,' he asserted, 'There are no walls around anthropological centers. ${ }^{49}$ Later, Hrdlička explained that the study of the 'primitive' races was crucial for understanding the principles of human development. 'Physical anthropology may not be of special benefit to the more primitive groups themselves, but we must have it not alone for descriptive and statistical purposes, but for a proper understanding of the fundamental problems of our own race and of humanity in general. ${ }^{50}$ Thus, the permanent exhibition of the Anthropological Museum at the Faculty of Natural Sciences of Charles University was to be as representative as possible, including the non-European specimens. ${ }^{51}$ Hrdlička himself donated numerous exotic specimens from various parts of the world.

There was an even greater ambition than that of scientific excellence and comparative research on the part of the Czech scholars - that of unfulfilled colonial ambitions. Throughout the second half of the $19^{\text {th }}$ century, what Ulla Vuorela has termed (for her case of Finland) 'colonial complicity' came to the fore in the Czech Lands too. That is, the Czechs were actively participating in hegemonic discourses as these were developed in Western Europe, thus identifying themselves with 'European' normative civilization and discursively degrading the non-European rest of the world. ${ }^{52}$ Within the frame of such colonial complicity, one of the objectives - often unconscious rather than calculated - of the newly founded scientific institutions in the Czech Lands were the efforts for not just a global outreach of Czech academia, but for their joining the civilizing efforts of similar institutions in the colonial metropoles. Deprived of possibilities of

47 The popular daily Národní listy [National Newspaper] reported on June 2, 1876, within the frame of an extensive article on Palacký's funeral, on the dissection of his head. 'The skull was extraordinarily beautiful, the brain plentiful and also nice. The brain was taken out of the head and deposited in a glass jar, to be preserved for eternal memory in the Czech Museum.' (For Palacký, see Zacek 1970).

48 Matiegka 1909.

49 Hrdlička to Matiegka, 30-X-1907, ASI-PAH, box. 44, file 'Matiegka'.

50 Hrdlička 1928, p. 20.

51 This vision of Prague constituting the center of European anthropological research was formulated in a letter of Aleš Hrdlička to President Tomáš Garrigue Masaryk of 22-III-1929, in Czech, in Bláha 2009, p. 109.

52 Vuorela 2009; for similar strategies in German Lands see Zantop 1997; for Czech Lands Lemmen 2018. 
physically dominating and exploiting the overseas regions, ${ }^{53}$ the Czechs could participate indirectly in the general colonizing thrust of Western Europe, through acquisition, description, and categorization of objects brought from afar. Present-day museums are inheritors of this ethos, and are still endowed with the authority to affirm what is historically and culturally significant. Therefore, before the scientific 'trophies', charged with political, cultural, and emotional meanings, are put to use, the way they came into their possession needs to be explored and taken into account. The offer from Nestler to the Museum of Man fitted this scheme perfectly.

After the purchase of the skulls from Nestler, Hrdlička donated several additional pieces from other parts of the Andean region (Pachacamac, Ancón and Chimaca) to the Anthropological Institute, to make the Andean collection even more representative. ${ }^{54}$ Matiegka's enthusiasm about the acquisition of these rarities was apparently shared by other members of the Czech anthropological community. Jiří Malý, Matiegka's assistant, was fascinated especially by the deformations, 'human intervention into the workshop of nature' ${ }^{55}$ It is interesting that in the period when Czech/Czechoslovak anthropology was still considering itself to be in the service of the nation, so that the study of domestic problems, including that of the 'national body' and its strengthening through application of eugenic expertise, hygiene, and nourishment, Malý chose precisely the exotic topic of prehistoric deformed skulls from South America for his habilitation. During his study trip to Great Britain and France in 1926 that immediately preceded the presentation of his habilitation, Malý communicated with renowned craniologists and gathered information about similar cases of artificial deformation. ${ }^{56}$ As he did not give any explanations for the choice of the object of study, we can only deduce that either a personal preference (probably inspired during Malýs acquaintance with Hrdlička and admiration for his comparative study of American material) or an effort to manifest the global outreach of Czechoslovak anthropology were at play.

But at the same time, Malýs processing of Nestler collection clearly reveals the limitations of such exotic endeavors pursued by Czech anthropologists, and the essential inability to insert them into context. The result of Malýs work was purely descriptive, a fact noted - and appreciated - by the evaluators of his habilitation

53 There had been certain colonial ambitions on the part of the Austro-Hungarian government already in the 19th century; and in the first decade of the $20^{\text {th }}$ century, the possession of Bosnia and Herzegovina to a certain degree satisfied the desire for territorial possessions to be exploited, studied and 'civilised'. See Sauer 2012.

54 According to his own statement, Hrdlička amassed more than 4,500 skulls during his expeditions to Peru in 1910 and 1913. (Letter of Hrdlička to Matiegka, 13-IV-1926, in Czech, NAA, Papers of Aleš Hrdlička, Box. 44, Matiegka Jindřich, 1924-1928). For his donation of the skulls to Prague, see the inventory of the Hrdlička Museum of Man, 1920-1921. The fact that deformed skulls were indeed attractive for Czech museum institutions could be further documented by the fact that the Moravian Land Museum (Moravské zemské muzeum), namely its anthropological collection built in the 1920s and 1930s by Karel Absolon, also received from Hrdlička plaster casts of trepanned skulls and three originals, from New Mexico, Bolivia, and Peru, in exchange for copies and original finds from prehistoric sites in Moravia. (Kostrhun 2015, pp. 600-601) Malý 1935, p. 36.

Letter from Malý to Matiegka, 1-VII-1926, in Czech, Archiv Národního muzea, Prague [Archive of the National Museum], fund 246 (Jindřich Matiegka), box 8 (Jiří Malý). 
thesis. ${ }^{57}$ As stated above, Nestler's collections did not contain any notes as to the origin of the specimens, and Malý thus had to work solely with the artifacts. When possible, he paired the skulls and the lower jaws, achieving twelve complete sets; he measured and compared them, trying to ascertain the sex, age, and other individual characteristics, and even speculated, on the basis of existing literature, on their ethnicity. But while Hrdlička and other scholars of the times made use of such material for far-reaching theorizing on the origin of mankind, Malý was apparently satisfied with merely identifying the valuable specimens. Even though he promised to follow up with a study on the possible impact of cranial deformation upon the brain, this was never realized. ${ }^{58}$

To make the collection more attractive for the visitors to the Hrdlička Museum of Man, Malý made castings of four of the deformed cavities and also commissioned the sculptor Miloslav Beutler to make a plaster bust of a deformed head, one of the first such reconstructions realized in Europe. ${ }^{59}$ a decade later Malý wrote an article on artificially deformed skulls from the prehistoric site Čelákovice (in central Bohemia), again making measurements and listing them in tables. ${ }^{60}$ But there was no effort to compare the two corpuses of skulls and to draw any general conclusions. As far as it is possible to ascertain, no further follow up research was ever done on Nestler collection. ${ }^{61}$ At present, the Bolivian skulls and skulls from Čelákovice are placed on the same shelves in the Hrdlička Museum of Man, which was founded in 1935 within the Anthropological Institute, together with the sculptural reconstruction of the elongated head of a 'South American Indian'.

\section{Conclusion}

Only in the second half of the $20^{\text {th }}$ century, the use of human remains - especially those remains coming from the formerly colonized regions - for scientific and educational purposes provoked first general discussion, then political action. Requests from indigenous movements for the transfer of human remains to their places of origin have appeared in North America, Australia, Canada, and New Zealand, and later in Africa, Asia, and Latin America from the 1970s. Some of them brought about legislative results. ${ }^{62}$ But, of course, the questions of displaying and researching human remains is a complex one and cannot be resolved unambiguously.

57 Report of a committee convened during the professors' board on March 18, 1927, for the purpose of evaluating the application of MUDr. J. Malý for habilitation in anthropology, in Czech, Archív Univerzity Karlovy [Archive of Charles University], Prague, fund PřFUK, no. 84 (Malý), f. 10-16.

58 Malý 1926. The article - a shortened version of the habilitation - also promised a second part dedicated to the description of the bones in the Nestler collection and also of the trepanations. This second part, however, was never published.

59 Photograph of the reconstruction in Škvařilová 2005, p. 12.

60 Malý 1935.

61 The exception is one M.A. thesis, whose author, after a lengthy introduction on various forms of artificial skull deformations all over the world, presented the results of the repeated measuring of the deformed heads from the Nestler collection and using improved craniological methods to ascertain age and sex. Again, the study is purely descriptive, with no aspirations for generalizations or comparisons. (Drápalová 2003)

62 Fforde et al. 2002; Giesen and White 2013; Giles and Williams 2016; Jenkins 2011; LaVaqueManty 2000. 
The ostentatious scientific rationality, the dismissive posture towards 'primitive' and 'archaic' ways of dealing with the dead - and with the living - was characteristic of many protagonists of physical anthropology in the final part of the $19^{\text {th }}$ and the beginning of the $20^{\text {th }}$ century, both in Europe and North America. While certainly resulting from complex processes of intellectual development in previous centuries and decades, at the moment it also served as argument for dominance not only over the rest of the world, but also over the lower classes in their own society. The ownership of precious scientific specimens, while in reality of little use in the development of science, brought prestige and publicity to the collectors, institutions, and nations that owned them. In a sense, the lust for 'marvelous possessions'63 that characterized the early phase of European overseas expansion remained present in museology of the modern era, and is a legacy that museums deal with to the present day.

While the debates on the repatriation of human remains have not, so far, reached Czech museums - even though these museums certainly faced the challenges of other types of repatriations and restitutions, be it the possessions of the Jews appropriated during the World War II, or the items confiscated from Germans after the war - there is still a need to start discussing these questions. It is also necessary to ascertain the specificities of human remains as well as, for example, religious objects in institutional holdings that go beyond the mere effort to prove the legality of their possession. This should start with the recontextualization of museum objects, their individual histories, appropriation, and the ways they are put to use at their present location. This was the principal aim of the present article.

\section{Literature:}

Achim, M. (2014). Skulls and Idols: Anthropometrics, Antiquity Collections, and the Origin of American Man, 1810-1850. In: P. L. Kohl, I. Podgorny, and S. Gänger, eds., Nature and Antiquities: The Making of Archaeology in the Americas. Tucson, pp. 23-45.

Appadurai, A. (1986). Introduction: commodities and the politics of value. In: A. Appadurai, ed., The Social Life of Things: Commodities in Cultural Perspective. Cambridge, pp. 3-63.

Bandelier, A. F. (1905). The Aboriginal Ruins at Sillustani, Peru. American Anthropologist, NS, 7(1), pp. 49-68.

Bandelier, A. F. (1911). The Ruins at Tiahuanaco. Proceedings of American Antiquarian Society, 21, pp. 218-265.

Bancel, N., Boëtsch, G., Deroo, E. and Lemaire, S., eds. (2012). MenschenZoos: Schaufenster der Unmenschlichkeit. Hamburg. 
Basu, P. (2011). Object Diasporas, Resourcing Communities: Sierra Leonean Collections in the Global Museumscape. Museum Anthropology, 34(1), pp. 28-42.

Bláha, P., ed. (2009). Aleš Hrdlička - 140. výročí narození [Aleš Hrdlička - 140 Anniversary of Birth]. Prague.

Blakey, M. L. (1987). Skull Doctors: Intrinsic Social and Political Bias in the History of American Physical Anthropology, with Special Reference to the Work of Aleš Hrdlička. Critique of Anthropology, 7(2), pp. 7-35.

Broca, P. (1875). Instructions craniologiques et craniométriques de la Société d'anthropologie de Paris. Paris.

Broca, P. (1878). Sur des crânes et des objets d'industrie provenant des fouilles de M. Ber à Tiahuanaco (Pérou). Bulletins de la Société d'anthropologie de Paris, 3(1), pp. 230-235.

Burger, R. L. (2009). The Life and Writings of Julio C. Tello: America's First Indigenous Archaeologist. Iowa City.

Challis, D. (2013). The archaeology of race: the eugenic ideas of Francis Galton and Flinders Petrie. London.

Cieza de León, P. (2005). Crónica del Perú. El Seňorío de los Incas, ed. Franklin Pease. Caracas [1553].

Córdova, V. (2006). Aymara Indians and their relationship to ancestors on display. In: J. Lohman and K. Goodnow, eds., Human remains and museum practice. New York, pp. 71-85.

Dokladal, M. and Brozek, J. (1961). Physical Anthropology in Czechoslovakia: Recent Developments. Current Anthropology, 2(5), pp. 455-456.

Drápalová, P. (2003). Umělé deformace lebek. Sbírka uměle deformovaných peruánských lebek v HMČ UK [Artificial Skull Deformations. Collection of artificially deformed Peruvian skulls in Hrdlička's Museum of Man of Charles University]. MA thesis, Charles University, Prague.

Edwards, E., ed. (1994). Anthropology and Photography, 1860-1920. New Haven - London.

Feldman, J. (2016). 'Miserable San Damian-But What Treasures!': The Life of Aleš Hrdlička's Peruvian Collection. History and Anthropology, 27(2), pp. 230-250.

Fenn, C. (1997). Life History of a Collection: The Tahotan Materials Collected by James A. Teit. Museum Anthropology, 20(3), pp. 72-91.

Fernando, H. R. and Finger, S. (2003). Ephraim George Squier's Peruvian Skull and the Discovery of Cranial Trepanation. In: R. Arnott, S. Finger and C. U. M. Smith, eds., Trepanation: History, Discovery, Theory. Lisse, pp. 1-20. 
Fforde, C., Hubert, J. and Turnbull, P., eds. (2002). The Dead and Their Possessions: Repatriation in principle, policy and practice. New York - London.

Flower, W. H. (1881). Fashion in Deformity, as illustrated in the customs of barbarous and civilized races. London.

Foster, R. J. (2012). Notes for a Networked Biography: The P.G.T. Black Collection of Oceanic Things. Museum Anthropology, 35(2), pp. 149-169.

Frič, A. V. (1977). Indiáni Jižní Ameriky [Indians of South America]. Prague.

Giesen, M. and White, L. (2013). International Perspectives towards Human Remains Curation. In: M. Giesen, ed., Curating Human Remains: Caring for the Dead in the United Kingdom. Woodbridge, pp. 13-40.

Giles, M. and Williams, H., eds. (2016). Archaeologists and their Dead: Mortuary Archaeology in Contemporary Society. Oxford.

Gould, S. J. (1996). The Mismeasure of Man, $2^{\text {nd }}$ ed. London.

Greenblatt, S. (1992). Marvelous Possessions: The Wonder of the New World. Chicago.

Grégr, E. (1858). O lebkách člověčích vůbec a o slovanských zvláště [On Human Skulls in General and on Slavic in Especial]. Živa, 6(4), pp. 223-242.

Herain, K. (1921). Výstava staroperuánského umění [Exhibition of Old Peruvian Art]. Drobné umění, 2(1), p. 16.

Herza, F. (2016). Anthropologists and Their Monsters: Ethnicity, Body, and Ab/ Normality in Early Czech Anthropology. East Central Europe, 43(1-2), pp. 64-98.

Herza, F. (2018). Imaginace jinakosti a přehlídky lidských 'kuriozit' v Praze v 19. a 20. století [Imagination of Otherness and the 'Freak' Shows in Prague in the $19^{\text {th }}$ and $20^{\text {th }}$ Century]. PhD thesis, Charles University, Prague.

Hrdlička, A. (1911). Some results of recent anthropological exploration in Peru. Washington.

Hrdlička, A. (1914). Anthropological Work in Peru in 1913, withe notes on the pathology of the ancient Peruvians. Washington.

Hrdlička, A. (1919). Physical Anthropology: Its Scope and Aims; Its History and Present Status in the United States. Philadelphia.

Hrdlička, A. (1928). 'The Full-Blood American Negro', American Journal of Physical Anthropology 12, pp. 15-30. 
Janko, J. (1997). Vědy o životě v českých zemích 1750-1950 [Life Sciences in the Czech Lands, 1750-1950]. Prague.

Janusek, J. W. (2004). Identity and Power in the Ancient Andes: Tiwanaku Cities Through Time. New York - London.

Jenkins, T. (2011). Contesting Human Remains in Museum Collections: The Crisis of Cultural Authority. London - New York.

Joyce, R. A. (2002). Academic Freedom, stewardship and cultural heritage: weighting the interests of stakeholders in crafting repatriation approaches. In: C. Fforde, J. Hubert and P. Turnbull, eds, The Dead and Their Possessions: Repatriation in principle, policy and practice. New York - London, pp. 99-120.

Jungová, G. (2017). Daneš the Collector: Pacific Journeys of J. V. Daneš and his Collection in the Náprstek Museum. Annals of the Náprstek Museum, 38(2), pp. 43-52.

Kopytoff, I. (1986). The cultural biography of things: commoditization as process. In: A. Appadurai, ed., The Social Life of Things: Commodities in Cultural Perspective. Cambridge, pp. 64-92.

Kostrhun, P. (2015). Američtí archeologové a antropologové na Moravě v období mezi světovými válkami [American archaeologists and anthropologists in Moravia in the interwar period]. Archeologické rozhledy 67, pp. 594-626.

Kroeber, T. (1961). Ishi in Two Worlds: a Biography of the Last Wild Indian in North America. Berkeley.

Křižzová, M. (2018). Julius Nestler: Gymnaziální profesor na stopě Atlantidy [Julius Nestler: High school professor on the trace of Atlantis]. Marginalia Historica, 9(1), pp. 89-99.

Lau, G. F. (2002). Feasting and Ancestor Veneration at Chinchawas, North Highlands of Ancash, Peru, Latin American Antiquity, 13(3), pp. 279-304.

Lavaque-Manty, D. (2000). There Are Indians in the Museum of Natural History, Wicazo Sa Review, 15(1), pp. 71-89.

Legassick, M. and Rassool, C. (2000). Skeletons in the Cupboard: South African Museums and the Trade in Human Remains, 1907-1917. Cape Town - Kimberley.

Lemmen, S. (2013). Noncolonial Orientalism? Czech Travel Writing on Africa and Asia around 1918. In: J. Hodkinson and J. Walker, eds., Deploying Orientalism in culture and history: from Germany to Central and Eastern Europe, Rochester, pp. 209-227.

Loring, S. and Prokopec, M. (1994). a Most Peculiar Man: The Life and Times of Aleš Hrdlička. In: T. L. Bray and T. Killion, Reckoning with the Dead: The Larsen Bay Repatriation and the Smithsonian Institution. Washington, DC, pp. 26-42. 
Lozada, M. C. (2014). The Emergence of Bioarchaeology in Peru: Origins and Modern Approaches. In: B. O’Donnabhain and M. C. Lozada, eds., Archaeological Human Remains: Global Perspectives. Cham, pp. 177-188.

Malý, J. (1926). Uměle deformované lebky z Tiahuanaco v Bolivii [Artificially Deformed Skulls from Tiahuanaco in Bolivia]. Anthropologie, 4(4), pp. 251-348.

Malý, J. (1935). Uměle deformované lebky z Čelákovic u Prahy [Artificially Deformed Skulls from Čelákovice by Prague]. Anthropologie, 13(1), pp. 37-53.

Massin, B. (1996). From Virchow to Fischer: Physical Anthropology and 'Modern Race Theories' in Wilhelmine Germany. In: G. W. Stocking, ed., Volksgeist as Method and Ethic: Essays on Boasian Ethngraphy and the German Anthropological Tradition, Madison, pp. 79-153.

Matiegka, J. (1893). Der Schadel des Samojeden Wasko. Mitteilungen der Anthropologischen Gesellschaft in Wien, 23, pp. 62-63.

Matiegka, J. (1909). O deformování lebek, zvláště s ohledem na prehistorické lebky deformované [On Deformations of Skulls, Especially with Respect to Prehistoric Skulls with Deformations]. Časopis Společnosti přatel starožitností v Praze, 17(2), pp. 156-158.

Nestler, J. (1913). Beiträge zur Kenntnis der Ruinenstätte von Tiahuanaco. Mitteilungen der Kais. Königl. Geographischen Gesellschaft in Wien, 56(4), pp. 227-236; 56(5), pp. 268-297.

Onderka, P., Jungová, G. et al. (2015). Egyptian Mummies and Coffins in the Collections of the Náprstek Museum: Adult Human Mummies. Annals of the Náprstek Museum, 36(2), pp. 23-48.

Penny, G. (2002). Objects of Culture: Ethnology and Ethnographic Museums in Imperial Germany. Chapel Hill.

Penny, G. (2003). The Politics of Anthropology in the Age of Empire: German Colonists, Brazilian Indians, and the Case of Alberto Vojtěch Frič. Comparative Studies in Society and History, 45(2), pp. 249-280.

Ponce Sanginés, C. (1995). Tiwanaku: 200 años de investigaciones arqueológicas. La Paz.

Quigley, C. (2001). Skulls and Skeletons: Human Bone Collections and Accumulations. Jefferson - London.

Redman, S. J. (2016). Bone Rooms: From Scientific Racism to Human Prehistory in Museums. Cambridge, Mass.

Roque, R. (2010). Headhunting and Colonialism: Anthropology and the Circulation of Human Skulls in the Portuguese Empire, 1870-1930. Basingstoke - New York. 
Roque, R. (2011). Stories, Skulls, and Colonial Collections. Configurations, 19, pp. 1-23.

Sauer, W. (2012) 'Habsburg Colonial: Austria-Hungary's Role in European Overseas Expansion Reconsidered'. Austrian Studies 20, pp. 5-23.

Skinner, J. (1805). Present State of Peru. London.

Squier, E. G. (1877). Peru: Incidents of Travel and Exploration in the Land of the Incas. New York.

Starn, O. (2004). Ishi's Brain: In Search of America's Last 'Wild' Indian. New York.

Steffal, V. (1877). Výsledek částečného pitvání mrtvoly Františka Palackého [Result of partial autopsy of the corpse of František Palacký]. Časopis lékařru českých, 16(22), p. 169.

Stocking, G. W. (1985). Essays on Museums and Material Culture. In: G. W. Stocking, ed., Objects and Others: Essays on Museums and Material Culture. Madison, pp. 3-15.

Škerlj, B. and Božek, J. (1952). Jindřich Matiegka and the development of Czech physical anthropology. American Journal of Physical Anthropology, 10(4), pp. 515-519.

Škrabáková, L. (2019). Hlava náčelníka z Náprstkova muzea [Chief's Head from the Náprstek Museum]. Věstník AMG, 29(1), p. 16.

Škvařilová, B. (2005). Sbírky HMČ UK - výzkumy přírodních národů [Collections of Hrdlička's Museum of Man - Research of the Natural Nations]. In: Antropologie ve sjednocené Evropě: Sborník přednesených př́spěvků (3. Memoriál prof. J. Matiegky a prof. J. Malého, 22. 9.-23. 9. 2005, Praha-Mělník), Prague, pp. 12-17.

Škvařilová, B. (2010). Hrdličkovo muzeum člověka Univerzity Karlovy [Hrdlička's Museum of Man of Charles University]. Prague.

Tello, J. C. (1913). Prehistoric trephining among the Yauyos of Peru. In: International Congress of Americanists. Proceedings of the XVIII session, London 1912. London, vol. 1, pp. $75-83$.

Tomsová, J. (2014). Egyptologická sbírka Hrdličkova muzea člověka Univerzity Karlovy v Praze [Egyptological Collection of Hrdlička Museum of Man of Charles University in Prague]. Pražské egyptologické studie, 12, pp. 56-67.

Virchow, R. (1892). Crania ethnica Americana: Sammlung auserlesener amerikanischer Schädeltypen. Berlin.

Vuorela, U. (2009). Colonial Complicity: The 'Postcolonial' in a Nordic Context. In: S. Keskinen et al., eds., Complying with Colonialism: Gender, Race and Ethnicity in the Nordic Region. Farnham, pp. 19-33. 
Wafer, L. (1934). a New Voyage and Description of the Isthmus of America, ed. L. E. Elliott Joyce. Oxford [1688].

Yates, D. (2011). Archaeology and autonomies: the legal framework of heritage management in a new Bolivia. International Journal of Cultural Property, 18(3), pp. 291-307.

Zacek, J. F. (1970). Palacký: the historian as scholar and nationalist, Hague - Paris.

Zantop, S. (1997). Colonial Fantasies. Conquest, Family, and Nation in Precolonial Germany, 1770-1870. Durham.

Zimmerman, A. (2001). Anthropology and Antihumanism in Imperial Germany. Chicago - London. 